\title{
DETEKSI GEN MX AYAM TOLAKI MENGGUNAKAN TEKNIK EKSTRAKSI DNA YANG BERBEDA
}

\author{
Muhammad Amrullah Pagala ${ }^{1^{*}}$ dan Niken Ulupi ${ }^{2}$ \\ ${ }^{1)}$ Jurusan Peternakan Fakultas Peternakan Universitas Halu Oleo \\ Jl.HEA Mokodompit Kampus UHO Anduonohu, Kendari 93232 \\ ${ }^{2)}$ Departemen Ilmu Produksi dan Teknologi Peternakan, Fakultas Peternakan, Institut \\ Pertanian Bogor Jl Agatis Kampus IPB, Darmaga, Bogor, 16680 \\ *E-mail:amroe74@gmail.com
}

\begin{abstract}
ABSTRAK
Penelitian ini bertujuan untuk mencari metode yang efektif dalam teknik ekstraksi DNA dari gen Mx (Myxovirus) ayam Tolaki. Gen Mx adalah gen yang bertanggungjawab terhadap kemampuan ayam untuk mertespon serangan penyakit viral seperti penyakit Flu Burung dan New Castle Disesase. Penelitian ini dilaksanakan mulai bulan April sampai dengan bulan Agustus 2013. Sampel penelitan terdiri atas 25 ekor ayam Tolaki dewasa, yang diperoleh dari pemeliharaan secara ekstensif oleh masyarakat di Kabupaten Konawe. Penelitian ini menggunakan kedua metode ekstraksi DNA yakni metode ekstraksi DNA secara konvensional dan metode Kit ekstraksi DNA. Selanjutnya hasil ekstraksi DNA diamplifikasi menggunakan mesin PCR. Produk DNA kedua metode tersebut kemudian dibandngkan dan dianalisis secara kualitatif. Secara umum kedua metode tersebut cukup efektif untuk menghasilkan kualitas DNA gen Mx yang baik. Ekstraksi DNA gen Mx dari kedua metode tersebut menghasilkan ukuran DNA dengan panjang $299 \mathrm{pb}$.
\end{abstract}

Kata Kunci : Gen Mx, Ayam Tolaki, Ekstraksi DNA, PCR

\begin{abstract}
The objective of this research was to find the effective method that is producing DNA of Mx gene of Tolaki chicken. Mx gene (Myxovirus) gene is the specific genes that control the ability of the animals to be resistant or susceptible to virus attacks (Avian influenza and Newcastle Disease virus). The study conducted from April to August 2013. A total 25 chickens Tolaki (aged 8-12 months) were obtained from extensive maintenance in Konawe Regency communities. The research was used both the DNA extraction conventional method and DNA extraction kit method. The result of DNA fragmenth was amplified with PCR machine (Polymerase Chain Reaction). The DNA product were compared and analyzed qualitatively. Source of DNA material are blood and feathers of Tolaki chicken. The study showed the extraction of DNA from blood samples showed slightly better quality of DNA (DNA band was thick and clean) compared with DNA samples from feathers (DNA band was thin and smear). However, generally the both techniques were effectively produced DNA. Extraction of DNA from both methods of DNA obtained with the Mx gene size was $299 \mathrm{bp}$
\end{abstract}

Key Words : Mx gene, Tolaki chicken, DNA extraction, PCR 


\section{PENDAHULUAN}

Ayam lokal atau lazim dikenal sebagai ayam buras (bukan ras) memiliki sejumlah sifat ekonomis, namun dalam pengembangannya ayam lokal di Indonesia sampai saat ini masih belum ditangani secara serius dan kontinu, upaya ke arah seleksi yang terarah pada karakteristik fenotipik tertentu masih sangat terbatas. Hal ini dapat dilihat masih tingginya keragaman sifat-sifat yang dimiliki, baik sifat-sifat tampilan fisik maupun produktivitasnya (Mansjoer, 2003). Tingginya keragaman sifat yang dimiliki ayam lokal merupakan potensi dasar dalam pembentukan galur ayam lokal asli yang murni dan unggul, melalui program seleksi yang berkesinambungan dan karakterisasi pada sifat-sifat khas yang menonjol.

Ayam Tolaki temasuk dalam kategori ayam lokal yang memiliki fenotip yang khas selain ayam lokal lainnya seperti: ayam Nunukan, Bangkok, Pelung, Nagrak, Sentul, Merawang, Merawas, Kedu hitam/putih, Kokok Balenggek, Tukong, Kate dan ayam Berugo. Ayam Tolaki termasuk salah satu dari 31 jenis ayam lokal yang memiliki karakteristik penampilan yang khas (Nataamidjaja dan Dwiyanto, 1994). Ayam Tolaki adalah ayam lokal asli Sulawesi Tenggara. Ayam ini memiliki pola warna bulu yang mirip dengan ayam hutan merah (Gallus gallus), sehingga ada yang menyebutnya sebagai ayam hutan. Sampai saat ini ayam Tolaki masih dikelompokkan sebagai ayam aduan, namun sesungguhnya dengan menilik postur tubuhnya, maka ayam Tolaki dapat diarahkan untuk tujuan produksi daging dan telur. (Pagala dan Nafiu, 2012;Pagala dan Aku, 2010).

Ayam lokal diketahui memiliki sejumlah sifat ekonomis, diantaranya kemampuan adaptasi yang tinggi pada lingkungan yang kurang baik dan memiliki daya tahan terhadap sejumlah serangan penyakit viral meskipun di lingkungan tropis seperti Indonesia prevalensi penyakit relatif lebih tinggi. Kondisi ini menyebabkan kinerja produksi ayam lokal menjadi tidak optimal.

Beberapa hasil penelitian mengungkapkan ayam lokal di Indonesia memiliki ketahanan cukup tinggi terhadap terhadap serangan penyakit viral seperti Avian Influenza (AI) dan Newcastle Disease (ND). Sifat antiviral ini diketahui dikontrol oleh gen Mx (Maeda, 2005; Sulandari, et al., 2010; Pagala, et al., 2013).

Penggunaan teknik molekuler dengan memilih genotipe gen kandidat yang resisten terhadap penyakit tertentu sebagai Marker Assisted Selection (MAS) diharapkan dapat mempercepat pembentukan jenis ayam lokal resisten terhadap beberapa penyakit yang mematikan seperti AI dan ND.

Salah satu teknik dasar molekuler untuk mengidentifikasi keberadaan sejumlah gen adalah teknik isolasi genom dan ekstraksi DNA. Bahan ekstraksi DNA dapat diperoleh dari bagian tubuh/jasad suatu makhluk hidup dengan asumsi bahwa DNA terdapat pada semua bagian tubuh makhluk hidup. Sumber atau asal suatu bahan ekstraksi serta metode ekstraksi yang digunakan dapat mempengaruhi kualitas dan kuantitas DNA yang dihasilkan.

Berdasarkan hal tersebut, maka penelitian analisis gen Mx ayam Tolaki dengan teknik ekstraksi DNA yang berbeda dilakukan untuk melihat efektifitas metode serta kualitas DNA yang dihasilkan. 


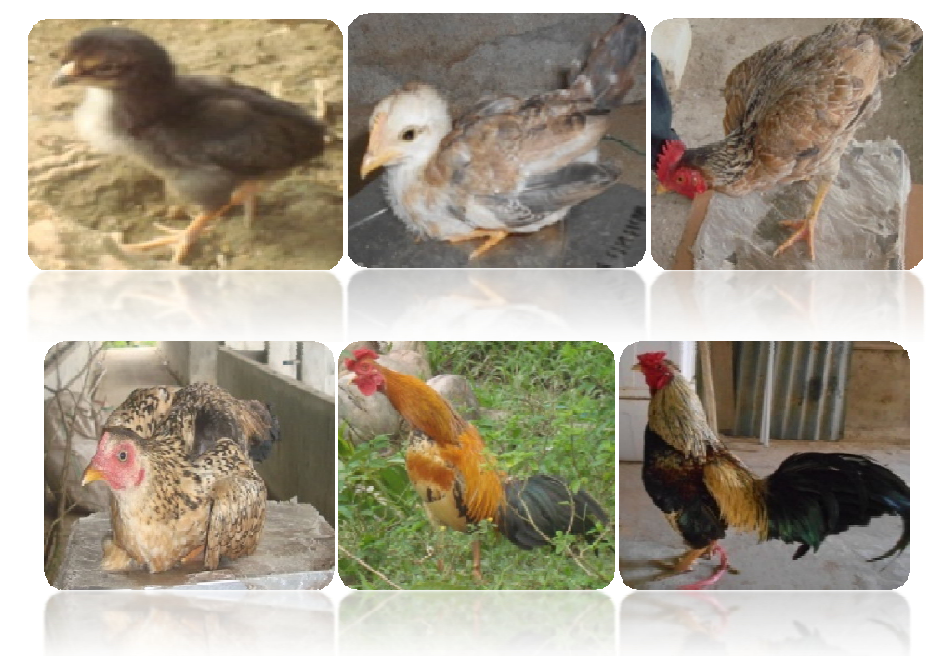

\section{MATERI DAN METODE}

\section{Tempat dan Waktu}

Lokasi penelitian bertempat
diLaboratorium Lapang Kandang Unggas Unit Pembibitan Fakultas Peternakan Universitas Halu Oleo. Ekstraksi DNA dan amplifikasi DNA gen Mx dilakukan di Laboratorium Pemuliaan dan Genetika Molekuler Departemen IPTP Fakultas Peternakan IPB. Penelitian dilaksanakan pada bulan April sampai dengan Agustus 2013.

\section{Materi Penelitian}

Sampel yang digunakan dalam penelitian ini adalah ayam Tolaki yang diambil dari beberapa daerah di Kabupaten Konawe Selatan Propinsi Sulawesi Tenggara sebanyak 25 ekor. Pengambilan sampel darah dan bulu dilakukan pada tahap I (pertama) penelitian, selanjutnya analisis laboratorium pada tahap II di Laboratorium Departemen IPTP Fakultas Peternakan IPB. Bahan yang digunakan adalah bahan kimia untuk pengambilan sampel darah, ekstraksi DNA, amplifikasi DNA, gel elektroforesis, dan Silver Staining antara lain : EDTA, Trs, HCL pekat, potassium aseat, air bebas ion, $\mathrm{NaCl}$,
$\mathrm{NaOH}$, SDA, natrium asetat, asam asetat, fenol, etanol absolute, kloroform, isoamil alkohol, dan proteinase $\mathrm{K}$, agarose, bromfenolblue, etidium Bromida, marker DNA leader $100 \mathrm{pb}$, Tris-Borat-EDTA, Mgcl2, dNTP, Taq polymerase dan random primer.

Alat yang digunakan mesin PCR, elektroforesis, autoclave, vacuum tainer, pipet mikro, pipet tip,disposable glove, sentrifuse, vortex, gelas piala, magnetic stirrer, tabung eppendorf, alat thremocycler, lampu UV, kamera paraloid.

\section{Metode Penelitian}

\section{Ekstraksi DNA dari Sampel Darah}

Sampel darah dalam tabung EDTAdimasukkan ke dalam tabung mikro $(1.5 \mathrm{ml})$ lalu ditambahkan dengan $1000 \mu \mathrm{DW} / \mathrm{TE}(\mathrm{NaCl} 0.2 \%)$. Setelah divortex dan didiamkan 5 menit, kemudian disentrifugasi pada kecepatan $8000 \mathrm{rpm}$ selama 5 menit. Larutan supernatan yang terbentuk dibuang. Tahap berikutnya dilakukan penambahan $40 \mu \mathrm{l}$ SDS $10 \%, 10 \mu \mathrm{l}$ proteinase $\mathrm{K} 5 \mathrm{mg} / \mathrm{ml}$, dan 1 x STE (Sodium Tris EDTA) sebanyak $300 \mu$ l. Larutan selanjutnya dikocok perlahan dalam inkubator bersuhu $55{ }^{\circ} \mathrm{C}$ selama 2 jam. Kemudian ditambahkan laruatn 
phenol $400 \mu 1,400 \mu 1$ CIAA (Chloroform:Isoamyl alkohol =24:1), dan $40 \mu \mathrm{l}$ NaCL $5 \mathrm{M}$ dikocok perlahan pada suhu ruang selama 1 jam lalu disentrifugasi pada kecepatan 12000 rpm selama 5 menit.

Larutan bening yang mengandung DNA dipindahkan sebanyak $400 \mu \mathrm{l} \mathrm{ke}$ tabung eppendorf $1.5 \mathrm{ml}$ yang baru. Selanjutnya ditambahkan $800 \mu \mathrm{l} \mathrm{EtOH}$ (etanol absolut), dan $40 \mu \mathrm{NaCl} 5 \mathrm{M}$. Lalu disimpan dalam freezer selama semalam. Tahap berikutnya larutan disentrifugasi lagi pada kecepatan 12000 rpm selama 5 menit, supernatan yang terbentuk dibuang lalu didiamkan dalam keadaan terbuka atau dalam desikator sampai alkohol hilang. Tahap terakhir ditambahkan $100 \mu \mathrm{l}$ TE $80 \%$ atau Elution Buffer yang berfungsi sebagai buffer. DNA yang diperoleh lalu disimpan dalam freezer sampai akan digunakan.

\section{Ekstraksi DNA dari Sampel Bulu}

Sampel bulu yang dapat digunakan merupakan sampel bulu utuh,ayam Tolaki yang memiliki bagian kalamus. Ekstraksi DNA dari sampel bulu dilakukan menggunakan kit ektraksi Phire Animal Tissue Direct PCR Kit (Thermo Fisher Scientific Inc.). Prosedur ektraksi dilakukan mengikuti petunjuk dari produsen kit sebagai berikut: $\pm 0.5 \mathrm{~cm}$ bagian awal (akar/kalamus) bulu dipindahkan kedalam tabung $1.5 \mathrm{ml}$, kemudian dipotong menjadi beberap bagian kecil. Pada tabung $1.5 \mathrm{ml}$ ditambahkan $20 \mu \mathrm{l}$ Dilution Buffer dan $0.5 \mu \mathrm{l}$ DNA Release ${ }^{\mathrm{TM}}$ Additive.

Campuran dalam tabung diaduk menggunakan vortex dan kemudian disentrifugasi. Setelah itu campuran diinkubasi selama 2-5 menit pada suhu ruang dan dilanjutkan selama 2 menit pada suhu $98{ }^{\circ} \mathrm{C}$. Sampel DNA siap digunakan atau disimpan pada suhu -20 ${ }^{\circ} \mathrm{C}$ untuk digunakan dikemudian hari.

\section{Amplifikasi Ruas Gen Mx dengan PCR}

Sampel DNA diamplifikasi dengan mesin PCR (Polymerase Chain Reaction) (Muladno, 2010). Primer spesifik untuk mengamplifikasi gen $\mathrm{Mx}$ berdasarkan Sironi et al. (2010) adalah primer foward (5'-GCA CTG TCA CCT CTT AAT AGA-3') dan reverse (5'-GTA TTG GTA GGC TTT GTT GA-3'). Amplifikasi DNA dilakukan pada total volume $25 \mu \mathrm{l}$ terdiri dari $2 \mu \mathrm{l}$ (10-100 ng) DNA, 15,75 $\mu 1$ air bebas ion steril; 2,5 $\mu 110 \times$ buffer tanpa, meliputi proses denaturasi awal pada suhu $94{ }^{\circ} \mathrm{C}$ selama 4 menit. Tahap II dilakukan dengan $30 \mathrm{x}$ siklus, meliputi denaturasi pada suhu $94{ }^{\circ} \mathrm{C}$ selama 10 detik, penempelan primerpada suhu 60 ${ }^{\circ} \mathrm{C}$ selama 1 menit, pemanjangan molekul DNA pada suhu $72{ }^{\circ} \mathrm{C}$ selama 2 menit. Tahap III dilakukan dengan $1 \mathrm{x}$ siklus, meliputi pemanjangan akhir molekul DNA pada suhu $72{ }^{\circ} \mathrm{C}$ selama 7 menit. Inkubasi pada $4{ }^{\circ} \mathrm{C}$ hingga digunakan untuk analisis lebih lanjut.

\section{Elektroforesis}

Elektroforesis fragmen DNA hasil amplifikasi dengan PCR dilakukan menggunakan perangkat elektroforesis pada gel agarosa $2 \%(0,5$ gram $/ 25 \mathrm{ml}$ $0,5 \quad X \quad$ TBE). Perangkat dijalan menggunakan buffer 0,5 X TBE, pada tegangan 100 volt selama 30 menit. Viasualisasi gel elktroforesis dilakukan pada perangkat dokumentasi gel Alpha Imager (Alpha Imager).

\section{Analisis Data}

Berdasarkan hasil ekstraksidan amplifikasi DNA selanjutnya dilakukan analisis secara kualitatif dengan cara membandingkan tampilan pita DNA 
yang dihasilkan dari kedua metode ektraksi DNA dalam gel elektroforesis.

\section{HASIL DAN PEMBAHASAN}

\section{Ekstraksi DNA ayam Tolaki}

Hasil ekstraksi DNA yang diperoleh dari ayam Tolaki menggunakan metode ekstraksi yang berbeda disajikan pada gambar 1 dan gambar 2

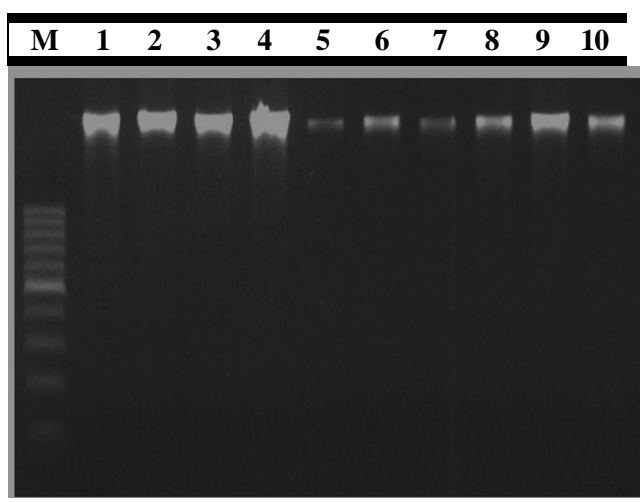

Keterangan : $\quad \mathrm{M}=$ DNA Marker $1 \mathrm{~kb}$ $1,2,3, \ldots=$ DNA Sampel

Gambar 1. Hasil ektraksi DNA darah ayam Tolaki

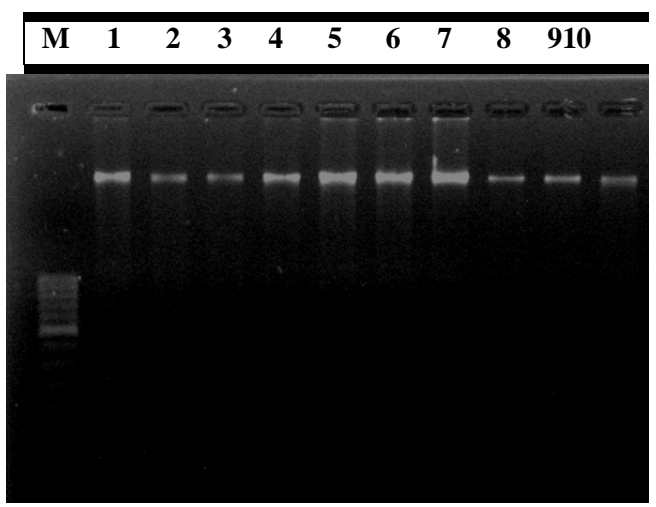

Keterangan: $\quad M=$ DNA Marker $1 \mathrm{~kb}$ $1,2,3, \ldots=$ DNA Sampel

Gambar 2. Hasil ektraksi DNA buluayam Tolaki
Teknologi ekstraksi DNA pada organisme eukaryot (manusia, hewan, dan tumbuhan) umumnya dilakukan dengan beberapa tahapan dasar seperti degradasi dinding sel, penghilangan RNA dan protein serta presipitasi dan purifikasi DNA.

Prosedur kerja dalam tahapan ekstraksi ini dapat digunakan untuk ekstraksi dari berbagai jaringan tubuh, darah, rambut, feses, tulang, sperma, urine, daun, kayu, jamur dan sebagainya. Berdasarkan prinsip dasar ini telah banyak dikembangkan berbagai teknik ekstraksi DNA, yang dapat dikelompokkan kedalam teknologi ekstraksi DNA konvensional dan teknologi Kit DNA (Sulandari dan Zein, 2003).

Berdasarkan hasil ekstraksi DNA ayam Tolaki dengan metode ekstraksi darah (teknik DNA konvensional) dan bulu (teknik DNA Kit) memperlihatkan kualitas DNA yang cukup baik. Seluruh sampel DNA terkumpul dengan baik pada stocking gel. Ekstraksi DNA dari sampel darah menunjukkan kualitas DNA sedikit lebih baik jika dibandingkan dengan sampel DNA dari bulu. Hal ini dapat dilihat pada pita DNA yang lebih tebal dan bersih, sedangkan pita DNA asal bulu lebih tipis dan memperlihatkan sebaran pita sedikti smear. Hasil ekstraksi DNA berupa tampilan pita DNA pada stocking gel bermakna bahwa semua sampel mengandung gen $\mathrm{Mx}$, namun belum diketahui berapa panjang ukuran DNA serta genotipe dari gen Mx ini.

Kedua teknik ekstraksi DNA yang telah diaplikasikan di atas memperlihatkan kelebihan dan kekurangan masing-masing. Teknik DNA secara konvensional menunjukkan hasil yang lebih baik dari teknik DNA Kit, namun kekurangannya membutuhkan waktu pengerjaan yang cukup lama dan tahapan lebih rumit, 
sedangkan teknik DNA kit prosesnya cukup mudah, cepat dan sederhana, namun untuk menghasilkan kulaitas pita DNA yang baik membutuhkan jumlah sampel yang cukup banyak (Fatchiyah, et al., 2011).

\section{Amplifikasi DNA Ayam Tolaki}

Hasil amplifikasi DNA dengan PCR ditampilkan pada Gambar 3 dan Gambar 4

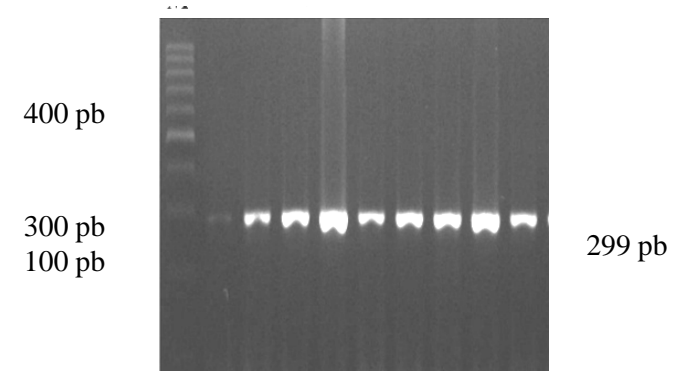

Keterangan : $\mathrm{M}=$ Marker $1 \mathrm{~kb}$ $1,2,3, \ldots=$ Jumlah sampel

Gambar 3 Hasil Amplifikasi PCR DNA sampel darah Ayam Tolaki

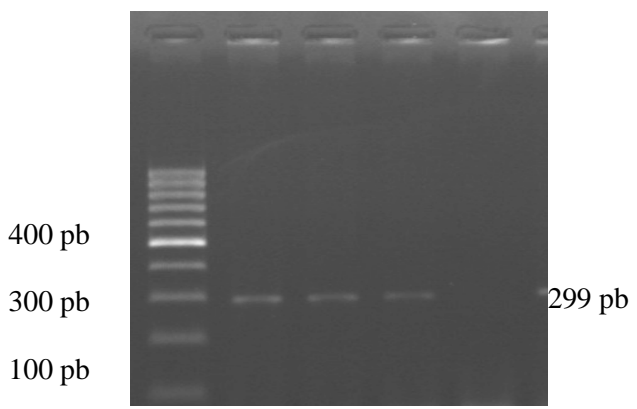

Keterangan: $\mathrm{M}=$ Marker $1 \mathrm{~kb}$ $1,2,3, \ldots=$ Jumlah sampel

Gambar 4 Hasil Amplifikasi PCR DNA sampel bulu Ayam Tolaki

Berdasarkan hasil amplifikasi PCR DNA pada sampel darah ayam
Tolaki diperoleh informasi bahwa semua sampel ayam Tolaki memiliki gen Mx pada exon 13 dengan ukuran pita DNA sebesar 299 pb. Produk PCR hasil ekstraksi DNA dari sampel darah memperlihatkan kualitas DNA yang lebih baik, hal ini dapat dilihat dari tampilan pita DNA yang lebih tebal dibandingkan pita DNA hasil ekstraksi DNA dari sampel bulu yang sedikit lebih tipis. Meskipun demikian kedua metode ekstraksi DNA diatas cukup efektif dan cukup baik digunakan dalam mendeteksi keberadaan gen Mx.

Gen Mx adalab 299 gen yang bertanggungjawab terhadap kemampuan ayam dalam mempertahankan diri terhadap serangan virus flu burung (Maeda 2005: Sulandari et al.2011;Sartika, 2010)) dan virus Newcastle Disease (Pagala et al, 2013). Ukuran pita DNA gen Mx pada ayam Tolaki sebesar 299 pb relatif sejalan dengan hasil penelitian yang dilaporkan oleh Sironi, et al. (2010) yang menemukan adanya gen Mx pada exon 13 ayam jenis White Leghorn dan New Hampshire sebesar $300 \mathrm{pb}$.

Penelitian awal terkait gen $\mathrm{Mx}$ pada ayam sebelumnya telah dilakukan oleh Ko, et al. (2002) dan Maeda (2005) yang menunjukkan gen $\mathrm{Mx}$ terletak pada kromosom 1, dengan panjang fragmen 20.767 pasang basa (pb), terdiri atas 13 exon, $1.115 \mathrm{pb}$ coding region, dan sisanya 705 asam amino. Gen Mx cukup efektif digunakan dalam program breeding yang ditujukan untuk meningkatkan mutu genetik rumpun ayam lokal yang tahan terhadap infeksi virus avian influenza dan Newcastle Disease (Sartika, et al., 2011; Pagala, et al., 2013)

\section{KESIMPULAN DAN SARAN}

Berdasarkan hasil penelitian, dapat ditarik kesimpulan sebagai berikut 
1. Metode ekstraksi darah menggunakan teknik DNA konvensional dan metode ekstraksi bulu menggunakan teknik DNA Kitmemperlihatkan kualitas DNA yang cukup baik.

2. Hasil ekstraksi DNA menggunakan teknik ekstraksi konvensional menghasilkan kulaitas DNA yang relatif sedikit lebih baik dibandingkan menggunakan teknik DNA Kit

3. Melalui ekstraksi DNA dan hasil amplifikasi dengan mesin PCR diperoleh DNA gen Mx dengan panjang ukuran 299 bp.

Untuk mendapatkan validasi hasil ekstraksi DNA yang lebih akurat menggunakan kedua metode ekstraksi DNA tersebut, maka dibutuhkan jumlah sampel yang lebih banyak dan proses optimasi yang lebih lama.

\section{DAFTAR PUSTAKA}

Fatchiyah, E.L.Aruminingtyas, S. Widyarti, S.Rahayu. 2011. Biologi molekuler Prinsip dasar analisis. Penerbit Erlangga. Jakarta.

Maeda. 2005. Polymorphism of Mx Gene in Asian Indigenous chicken population. Seminar Nasional Tentang Unggas Lokal III: 25 Agustus 2005. Universitas Diponegoro. Semarang

Mansjoer SS. 2003. Potensi ayam buras di Indonesia. Makalah semiloka pengkajian pengembangan produksi bibit ayam Buras dan Itik, Cisarua Bogor, Tanggal 11 12 Desember 2003.

Nataamidjaja A.G. dan K. Diwyanto, 1994. Konservasi Ayam Buras Langka. Proceeding, Koleksi dan Karakterisasi Plasma Nutfah Pertanian, Bogor.
Pagala, M.A., Muladno, C.Sumantri \& S.Murtini. 2013.Association of Mx Gene Genotype with Antiviral and Production Traits in Tolaki Chicken.J. Poult Sci. 12 (12): 735-739.

Pagala MA, dan L.O. Nafiu. 2012. Identifikasi molekuler sifat anti viral ayam Tolaki melalui deteksi gen Mx sebagai marka genetik. Agriplus. 23:139-144.

Pagala M.A, dan A.S. Aku. 2010. Studi Sebaran dan Pemetaan Populasi Ayam Tolaki di Kabupaten Kolaka dan Kolaka Utara dalam rangka pelestarian plasma nutfah asli Sulawesi Tenggara. Warta Wiptek Volume 18 Edisi Januari 2010.

SambrookJ., F.Fritsch, \& T. Maniatis. 1989. Molecular Cloning. A Laboratory Manual $2^{\text {nd }}$ ed. (US) : Cold Spring Harbor Laboratory Press.

Sartika T., S. Sulandari, \& MSA. Zein,. 2011. Selection of Mx gene genotype as genetic marker for Avian Influenza resistance in Indonesian native chicken. BMC Proceed. 2011, 5(Suppl 4):S37.

Sartika, T. 2005. Gen $\mathrm{Mx}^{+}$sebagai penyeleksi resistensi flu burung. Warta Penelitian dan pengembangan pertanian (27). 2005 .

Schwarz H, O.Harlin, A.Ohnemus, B.Kaspers, \& P.Staeheli. 2004. Synthesis of IFN- $\beta$ by virus infected chicken embryo cells demonstrated with spesific antisera and new bioassay. $\mathrm{J}$ Interf Cyt Res. 24:179-184.

Sironi, L., P. Ramelli, J.L.Williams, \& P.Mariani. 2010. PCR-RFLP Genotyping Protocol for Chicken Mx Gene G/A Polymorphism associated with the S631N 
Mutation. Genet Mol Res. 9(2):1104-1108.

Staeheli P, R. Grob, E. Meir, J. Sutcliffe, \& O.Haller. 1998. Influenza-susceptible mice carry Mx genes with a large deletion or a nonsense mutation. Mol Cell Biol. 8(10):4518-4523.

Sulandari S., MSA Zein, D. Astuti, \& T.Sartika. 2009. Genetic polymorphisms of the chicken antiviral Mx gene in a variety of Indonesia indigenous chicken breeds. J Vet. 10(2): 50-56.

Sulandari, S, dan M.S.A. Zein. 2003. Panduan Praktis Laboratorium DNA. Buku. Edisi Pertama. Bidang Zoologi, Pusat Penelitian Biologi. Lembaga Ilmu Pengetahuan Indonesia. Bogor. hlmn.125. 